\title{
ECONOMIC DEVELOPMENT: THEN AND NOW
}

\author{
M A B SIDDIQUE ${ }^{1}$
}

DEVELOPMENT ECONOMICS as a separate branch of economics emerged at the end of the Second World War. During the dominance of neo-classical economics from the 1870s until the Keynesian Revolution of the 1930s, economists were more concerned with partial equilibrium analysis. They worked on the assumption that a free competitive capitalist economy would automatically ensure the maximisation of national output at full employment. The idea that a competitive market economy based on individualism and freedom of enterprise maximises economic growth (in the long-term) was fundamental to Classical Economics. Adam Smith was sympathetic to the capitalist class. Among the Classical Economists, J S Mill however had a somewhat ambivalent attitude to both capitalism and economic growth. At one stage of his life, Mill became an admirer of socialism and argued against the advantages of a growth-oriented free market economy.

The Great Depression (1930-31) was a new turning point in economic thinking. In his General Theory of Employment Interest and Money, Keynes argued that a free enterprise economy could lead to (permanent) underemployment equilibrium. Thus Keynes challenged the fundamental basis of Classical Economics and called for governmental intervention to create full employment through public works and deficit financing. The Keynesian short-run analysis was extended by Harrod and Domar to examine the conditions for long-term steady-growth of the capitalist society. Harrod and Domar initiated new interest in macroeconomic analysis in the post-1945 period in which a large number of mainstream economists got involved. The central issue in the post-war discussion on growth literature was how to maintain full employment and economic growth (i.e., an increase in real per capita income) at a steady rate by avoiding cyclical fluctuations.

The post-World War II period also witnessed the end of the long era of European colonisation of Asia and Africa. The newly emerging independent countries in the 1950s were eager to bring about rapid economic transformation to improve the living standards of the masses. It was in this context that the distributional aspects of economic growth were first brought into open discussions and the first dividing line was drawn between economic growth and economic development.

The question of distribution of income did not receive any serious attention in earlier literature. It was believed that distributional aspects will be taken care of by the 'trickle down effect' of growth. However, by the middle of the 1970s, it became clear that growth did not automatically guarantee more equal distribution of its fruits. Indeed, without corrective measures, economic growth in the sense of a higher rate of increase in GDP would normally tend to accentuate inequalities of income and wealth at least in the shortterm. In the longer term sustained economic growth could of course lead to structural

\footnotetext{
${ }^{1}$ Director, Centre for Migration \& Development Studies, and Lecturer, Department of Economics, The University of Western Australia. For his helpful comments on earlier drafts of the paper, I am thankful to Dr Robin Ghosh, Senior Honorary Research Fellow, Department of Economics, The University of Western Australia.
} 
changes in the economy such as urbanisation, improvement in health care, reduction in infant mortality, improved opportunities for education - in brief, changes which in their totality constitute what is called 'economic development'. From the point of view of a development economist, the important question is, how long is the long-run before economic growth would translate into economic development?

\section{SUSTAINABLE DEVELOPMENT}

The other aspect of the development issue is of course its sustainablity. With the publication of Our Common Future by the World Commission on Environment and Development (often referred as the Brundtland Report, after Gro Harlen Brundtland, Prime Minister of Norway, who chaired the Commission) another dimension was added to the concept of development: Sustainability. Sustainability of development or sustainable development emphasises the need for integration of economics and environment as well as promotion of intra-and intergenerational equity ${ }^{2}$. The fundamental idea behind sustainable development is that the needs of the present generation must not be met at the expense of the future generations. It was defined in Our Common Future as "development that meets the needs of the present without compromising the ability of future generations to meet their own needs" (World Commission on Environment and Development 1987:43). The necessity to put a cap on development by the current generation arises due to the delicate and 'fragile' characteristic of the nature which is described by the Brundtland Commission in the following words:

"Nature is bountiful, but it is also fragile and finely balanced. There are thresholds that cannot be crossed without endangering the basic integrity of the system. Today we are close to many of these thresholds; we must be ever mindful of the risk of endangering the survival of the life on earth" (World Commission on Environment and Development 1987:32ff).

Indefinite growth of whatever sort cannot be sustained in an environment of finite resources, particularly non-renewable resources such as minerals, fossil fuel, etc. There is also the question of a long-term disruption of a stable ecology caused by pollution of atmosphere and water due to pressures of GDP-promoting activity. In general, the simple rule of ecological balance and stability is based on ecological diversity. Growth of human numbers coupled with industrialisation and development, would inevitably tend to simplify a very complex and diverse ecology that has taken millions of years to evolve to its present stage. In the 1980s many development economists were therefore concerned with broader issues of development such as environment, ecology and sustainability as the critical factors to be considered by developing countries.

Indeed, it is now generally recognised by the International Monetary Fund (IMF) and the World Bank that per capita real income is a very imperfect measure of the quality of life in terms of environment, education, health, life expectancy and similar issues.

The introduction of the concept of sustainable development sparked environmental debates in many countries. Environmentalists have argued that the traditional definition of economic development (in terms of a sustained increase in real GNP or NNP) is quite

\footnotetext{
${ }^{2}$ The concept of sustainable development was first given currency by the World Conservation Strategy (IUCN 1980).
} 
inadequate as it fails to take into consideration the costs associated with the use of environment. If allowance for use of environmental resources is taken into consideration, the real rate of growth would be much less than is actually calculated by applying the traditional method of growth measurement ${ }^{3}$. Environmental economists have shown that it is possible to calculate net national product by taking into consideration the waste of natural resources (due to various economic activities which require the use of natural resources) into national accounts. Following Dasgupta and Mäler (1991), Hartwick (1990 and 1992), and Mäler (1991) it is possible to argue that the calculation of NNP should take into account any damage to current environment due to economic activity. Then,

Gross Investment $=$ Net Investment + Depreciation of Stock of K

and $\quad \mathrm{NNP}=$ Consumption + Net Investment - Damage to current environment + Net change in human capital

where, NNP $=$ Net National Product and

$\mathrm{K}=$ Stock of real (natural) capital

The above definition of NNP takes into account the quality of life and environment.

Since the publication of Our Common Future, the concept of sustainable development was further modified and extended by development economists. In Caring for the Earth (IUCN/UNEP/WWF 1991) sustainable development is defined as improvement in "the quality of human life while living within the carrying capacity of supporting ecosystems" (quoted in Munro 1995:29). It should be noted here that improvement in the quality of human life subject to environmental or ecological constraint is the main focus of this definition. Sustainable development must "continue or its benefits must be maintained, indefinitely. This means that there must be nothing inherent in the process or activity concerned, or in the circumstances in which it takes place, that would limit the time it can endure. It also means that it must be worthwhile; it must meet the social and economic objectives..."(Munro 1995:28). This multidimensional aspect of sustainable development was not overlooked by Brundtland himself. According to him:

"There are many dimensions to Sustainability. First it requires an elimination of poverty and deprivation. Second, it requires the conservation and enhancement of the resources base which alone can ensure that the elimination of poverty is permanent. Third, it requires a broadening of the concept of development so that it covers not only economic growth but also social and cultural development. Fourth, and most important, it requires the unification of economics and ecology in decision making at all levels." (Gro Harlen Brundtland - quoted in Pearce, et. al. (1989:174-75).

Of all the dimensions of sustainable development mentioned above, elimination of poverty, in particular rural poverty in the third world, is of crucial importance. A large number of people in the rural areas depend on the environmental resources such as forests, irrigation water and fisheries. In the absence of any definite plan to reduce rural poverty, growth in rural population increases the pressure on the environmental resources which leads to environmental degradation. "As the environment degrades and poverty intensifies, desperate people accelerate the process with even more intensive use, straining the already

\footnotetext{
${ }^{3}$ See, Repetto et al., $(1989,1992)$. Repetto observed that if the depreciation of oil, forests, and soils was included in the national income accounting of Indonesia, the average annual growth rate from the early 1970s to the middle of the 1980s would be half the actual growth rate as calculated by the traditional accounting system.
} 
fragile and limited environmental base beyond its capacity for repair and renewal." (World Bank 1995:2).

Since the late 1980s, the environmentalists have become a dominant force in decision making processes in many countries. Environmental protection bodies have been established with legal powers to approve or disapprove development projects in a number of countries. Policy-makers now have to take into consideration not only the size of GDP but also the quality of life, protection of environment and preservation of natural resources for future generations. 'Environmental conditionality' is also receiving increased attention from bilateral and international donor agencies.

\section{STRUCTURAL ADJUSTMENT PROGRAMMES (SAPs)}

Despite the emphasis on various economic and demographic factors which were supposed to propel economic change, there has been little long term economic development in many parts of Africa and Asia in the past five decades since the end of the World War II. The international financial agencies, particularly the IMF and the World Bank, came up with the idea of structural adjustment programmes (SAPs) as a precondition for development in the Third World.

For Africa in the 1980s, SAPs were adopted in the light of the World Bank document entitled Accelerated Development in Sub-Saharan Africa: an Agenda for Action (1981) which was influenced by the Laos Plan of Action of 1980. SAPs mainly involved: (i) trade liberalisation, (ii) labour market reforms, (iii) removal of foreign exchange control, (iv) budgetary adjustments to avoid deficits, and similar other measures, which would lead to the integration of a national economy to the globalisation process.

In Asia also, the IMF and the World bank initiated similar economic reforms in countries such as Bangladesh, India and Pakistan. The economic liberalisation programme in India that began in July 1991 has drawn world-wide attention of economists. The short term effects of economic reforms have generally had beneficial effects on economic growth in South Asia. However, even these short-term beneficial effects were not realised in many SubSaharan African Countries. In a comparatively recent paper, Samanta (1996) has clearly shown the failure of stabilisation and structural adjustment programmes (SAPs) in Kenya. The impact of SAPs on Sub-Saharan Africa as a whole for the period 1987-91 has been well below expectations (see, O'Brien 1994:51). Actually, the present author (1996a) has shown how this region experienced negative growth in exports and in real per capita income in the 1980s and failed to use the huge amount of external financial assistance (which it received from various bilateral and international donors in the 1970s and 1980s) for productive purposes. Consequently, in more recent years, the region has been plunged into an external debt crisis. In fact, in one of its papers "Adjustment in sub-Saharan Africa: progress, payoffs and challenges" the World Bank recognised that 14 out of 29 countries adopting SAPs experienced negative growth during 1987-91. No improvements were noticed in other key determinants of economic growth for the region as a whole: investment rates declined from 21 per cent in the 1970s to 18-19 per cent in the 1980s; domestic savings rate also fell (O'Brien 1994:51).

It is true that there is currently a sense of euphoria among liberal economists who believe that the trend towards globalisation through structural adjustments and free markets would eventually solve the problems of poverty and underdevelopment. But it is arguable 
whether economic liberalization and globalization would hold the key to future economic successes in the Third World.

\section{GOVERNANCE AND DEVELOPMENT}

The literature on economic development has now reached the cross roads: some still advocate the strengthening of the process of economic liberalisation as the ultimate goal for development economics. However, there are now concerns that the road to globalisation and liberalisation would not solve the problem of underdevelopment. Another path to development has to be followed to alleviate poverty and reduce inequalities. This is the path of good governance.

Reference to Governance in relation to economic development was first made in Sub-Saharan Africa: From Crisis to Sustainable Growth published by the World Bank in 1989. In that publication the Bank observed that the inefficient public sector management was a critical factor in the rapid economic decline of Sub-Saharan Africa in the 1970s and the 1980s (World Bank 1989:27). ${ }^{4}$ In other words, the Bank blamed the "poor governance' of a number of Sub-Saharan African countries (such as Ghana and Nigeria) for the failure of its recommended structural adjustment programmes which were mainly designed to attract private capital for achieving sustained growth in this region.

The turning point in the debates on development was the publication of the World Bank's Governance and Development (1992a). The Bank defined governance as "the manner in which power is exercised in the management of a country's economic and social resources for development" (World Bank 1992a:1) and identified four major components of governance: (i) public sector management; (ii) accountability; (iii) the legal framework for development; and (iv) transparency and information.

The Bank was of the view that sustainable development required "a predictable and transparent framework of rules and institutions for the conduct of private and public business. ...Good governance is epitomized by predictable, open and enlightened policy making, a bureaucracy imbued with a professional ethos acting in furtherance of the public good, the rule of law, transparent processes, and a strong civil society participating in public affairs. Poor governance is characterised by arbitrary policy making, unaccountable bureaucracies, unenforced or unjust legal systems, the abuse of executive power, a civil society unengaged in public life, and widespread corruption. Good governance fosters strong, but sharply delimited states capable of sustained economic and social development and institutional growth. Poor governance undermines all efforts to improve policy making and to create durable institutions. Since so much of what the Bank seeks to achieve through its lending is at risk to indifferent or poor governance, governance is a vital matter for the Bank." (Governance: The World bank's Experience). ${ }^{5}$

Promotion of 'good governance' for the purpose of achieving sustainable development became one of the major objectives of the World Bank in the 1990s. As a matter of fact, "the typing of official aid disbursement to the quality of governance... has

\footnotetext{
${ }^{4}$ For details see, Lancaster (1993).

5 [Online] Available: http://www.worldbank.org/html/hcovp/reports/governan.html.
} 
become a norm" in the 1990s (Moore 1993:1). ${ }^{6}$ The Bank's efforts in this respect centered around the efficient management of the public sector of the borrowing nations, improvement in the accountability of their public sector, improvement in transparency and information, and introduction of legal framework for development (Governance: The World Bank's Experience). "Good governance, in the Bank's view, has become a means to the end of sustained economic growth in the developing world and above all, in Africa" (Lancaster 1993:9).

Is good governance a necessary condition for economic development? The basic ingredients of good governance prescribed by the Bank seem to be very impressive. However such conditions are seldom fulfilled. As Moore (1993:4) observes, "The authors of Governance and Development seemed surprisingly uninterested in learning about the kind of governance practiced in countries which have been economically successful in recent decades, notably those of East Asia. Overall, the Bank's position is a mixture of informed good sense and Western (liberal) ideological bias. It is useful in parts and misleading or inadequate in others. It does not provide a good guide to good government generally." Moore (1993:2) also argues that the focus of governance issues by the World Bank is an attempt "to redefine the problem it faces when its own economic doctrine is actually tested in countries in Sub-Saharan Africa and found wanting." Some skeptics even go on arguing that the issue of governance has been picked up by the international donors (a) to find justifiable arguments for "further and further cuts in Third World aid"; and (b) to protect the interests of finance capital in Africa. Foreign capital operates with less hassles in liberal democratic regimes by controlling and influencing the mass media and political parties (Ibid. 2-3).

However, Boeninger (1992:267) argues that "governance affects sustained development, incorporating economic growth with social equity and human rights." North (1990) also holds similar views and asserts that quality of governance and development are highly correlated (cited in Landell-Mills and Serageldin 1990:303).

Leftwich (1994:3673) argues that the World Bank's "perception for good governance is naive... because it fails to recognise that good governance is a function of state character and capacity which is in turn a function of politics." The World Bank's approach "which presents governance almost as if it were an autonomous administrative capacity," is "detached from the turbulent world of politics and the structure and purpose of the state" (Ibid.). Leftwich further goes on arguing that "an effective public capacity for promoting development is not a function of good governance, as currently understood, but of the kind of politics and state that can alone generate, sustain and protect it... it has been the existence of effective 'developmental states' (whether democratic or not) which has accounted for the most successful records of economic development in the third world over the last thirty years. Unattractive as many of these states may be from a liberal or socialist point of view, they have been highly effective in raising the material welfare of the majority of their citizens within a generation" (Leftwich 1994:365).

The Bank's perception of the role of state has been very different from the role actually played by the state in many of the newly industrialising countries. The Bank's new model of Public Sector Management "requires a smaller state equipped with a

\footnotetext{
${ }^{6}$ The stipulation of the quality of government imposed by the aid agencies for the disbursement of official aids came to be known as 'political conditionality'. See Moore (1993:1).
} 
professional, accountable bureaucracy that is able to provide an 'enabling environment' for private sector led growth to discharge core functions like economic management effectively and to pursue sustained poverty reduction.” (World Bank 1994).

\section{GLOBALISATION AND ECONOMIC DEVELOPMENT}

With the establishment of the WTO and the end of the Cold War after the collapse of the old Soviet Union, the question of globalisation has received renewed interest from politicians and economists. The pre-1945 colonial era had led to some forced globalisation within the Empire between the mother country and her colonies. The Great War (19141918) put an end to this process of globalisation, and the attempt to restore it in the post-war years failed with the breakdown of the international gold standard. One country after another reverted to retaliatory tariffs and the free flow of goods and services virtually came to an end during the Great Depression (1930-31). Soon afterwards the World War II broke out. The process of globalisation began again only in the second half of the twentieth century (Williamson 1996:277).

Williamson argues that globalisation stimulates economic growth and convergence (defined in terms of a fall in the gap in living standards between rich and poor over time). On the contrary, deglobalisation leads to slow growth and divergence (ibid.) Based on the experience of globalisation and convergence by the members of the OECD club between 1854 and 1909, Williamson concludes that "history offers an unambiguous positive correlation between globalisation and convergence" $($ ibid.). However, one should be careful about the impact of globalisation on convergence with respect to a particular country. Delong's (1988) findings suggest that much of the convergence theory disappears if one extends the scope of the study beyond the OECD countries and includes Eastern Europe, and if it were widened still further to include the Third World, convergence would totally evaporate (cited in Williamson 1996:279).

Globalisation leads to redistribution of income and wealth. In the process, some countries gain and some lose. It was believed by many in the 1970s that "globalisation, rather than benefiting all nations, tended to produce gains for some at the expense of the others, but the general view was that integration of the world markets produced 'uneven development', a rise in the living standards of rich nations at the expense of the poor, rather than the other way around. The claim that a global marketplace tends to widen inequality among nations was used to justify demands for aid and commodity price support schemes. More radical theorists argued that the South could develop only if it 'delinked' its economies from the too well-established North. (Krugman and Venables 1995:858).

Three dominant features of the Third World countries determine the cost/benefit from globalisation: (i) export of primary commodities and import of manufactured goods, (ii) existence of surplus labour, and (iii) scarcity of capital. Globalisation in terms of free flow of goods and services for these countries would require the following: liberalisation of trade policies; emigration of surplus population, and import of foreign capital in terms of direct foreign investment.

The thesis developed by Singer (1950) and Prebisch (1962) does not support the idea that liberalisation of trade would benefit the primary commodity exporting developing countries as the terms of trade would go against them. Therefore it would be sensible for such countries to engage in industrial production by developing protective walls. The rapid 
industrial development of Japan since the 1950s exhibits the success story of a protective trade and industrialisation policy.

As regards international mobility of labour, Williamson (1996:291) argues that emigration of labour from low-wage countries to high-wage countries leads to the gains of the host country as it decreases the price of labour and therefore increases net return on capital. Ireland is cited as a net loser due to mass emigration (to the United States) in the 19th century. It is argued that Ireland failed to industrialise as "the best was being creamed off the top of the labor force"(Ibid.). Large-scale migration of labour which was a common scenario in the nineteenth century was restricted early in the twentieth century as the process of deglobalisation was put in motion. However with renewed trend in globalisation in the late twentieth century it has been happening again. Countries such as Australia, New Zealand, Canada, and the United States depend a lot on developing countries for the supply of labour. Emigration of skilled labour such as academics, engineers and doctors does create problems. The cost of training a highly skilled workforce is very high. Hence emigration of professionals from developing to developed countries is regarded as "reverse foreign aid" and "brain drain". According to one estimate, during 1972 the United States saved \$883 million in education costs, against a loss of $\$ 320$ million for Third World due to migration of skilled labour to the USA. During the period 1961-1972 Canada, Britain and the United States gained in higher income $\$ 44$ billion more than the income loss by developing countries (Agarwal and Winkler 1985:623; quoted in Hodgendorn 1992:312). Some development economists have recommended the imposition of a brain-drain tax (supplementary income tax) on earnings of emigrants to compensate for the losses of the Third World.

Another aspect of globalisation is the removal of restrictions on capital and investment flows. There is no doubt that developing countries need foreign capital for promoting economic development. But the literature dealing with the long-term impact of the activities of multinational corporations (MNC) on the development of the host nation remains inconclusive. Using the classical and neoclassical models it is possible to demonstrate that direct foreign investment (DFI) leads to increased tax revenues, increased labour income (or employment), and favourable externalities, particularly technological diffusion and training (Ruffin 1993). Advocates of DFI generally argue that direct foreign investment could fill a number of gaps (such as savings gap, foreign exchange gap, skill gap and technological gap).

However, using the general equilibrium analysis Brecher and Diaz-Alejandro (1977), Bhagwati and Brecher (1980, 1981), Bhagwati and Tironi (1980), Brecher and Findlay (1983) have "uncovered circumstances in which capital inflows may reduce welfare in the host country via domestic distortions or rigidities that limit income gains to less than the cost of the external capital, negative terms of trade effects, etc." (Helleiner 1989:1451).

\section{CORRUPTION, GOVERNANCE AND DEVELOPMENT}

Since the publication of Good Governance in 1992, economic as well as political conditionality has become part of aid packages. Earlier failures of achieving desired results through economic conditionality prompted donor agencies to introduce and impose political conditionality. Political conditionality is basically aimed at promoting democratic reforms, improving human rights and enhancing administrative efficiencies (Robinson 1995:1). Most of the ingredients of political conditionality are embodied in the 
term 'good governance'. However, the fundamentals of good governance perceived by the World Bank and the bilateral donors are not the same although they are not identical. As mentioned earlier, the World Bank's definition of good governance refers to financial accountability, administrative efficiency, legal framework of development, and transparency and information. However, bilateral donors are more concerned with the political dimension of governance such as democracy, human rights, and participation at the grass roots. (Moore 1993b). Accountability, transparency, free flow of information and administrative efficiency may all be lost if a nation is run by a corrupt government. On the other hand, if bilateral donors want to promote their perception of good governance, it has to be through a kind of Western democratic system where participation and human rights are guaranteed. Therefore, the form of government, administrative efficiency, accountability, transparency and free flow of information are all interlinked and cannot be achieved if a nation is dominated by widespread corruption. Both the 'democratisation agenda' of bilateral donors and the 'good governance' agenda of the World bank need a less corrupt society.

Does corruption promote or retard development? How is it linked to the economic and political conditionality of the World Bank and the bilateral donors? It should be noted here that a number of countries (such as Japan, South Korea and some other countries in East and Southeast Asia) are achieving respectable rates of economic growth in spite of rampant corruption prevailing at various levels in these countries. Whether corruption promotes or retards growth is a debatable issue. Economic analysis on corruption centres around its allocative effect of resources. Khan (1996:14) observes that corruption may have both primary and secondary effects on allocation of resources. The primary economic effect of corruption is that it leads to the final use of a resource by someone other than the one who would have had access to the resource otherwise. However, the allocative effect of corruption may leave beneficial effect on the economy if 'the post-corruption allocation is more efficient or welfare promoting than the initial allocation (Ibid.). Leff (1979) used such reasoning to conclude that the effect of bureaucratic corruption on economic development can be beneficial. Corruption takes place in the process of creating and transferring useful rights to agents who are responsible for the production of goods and services in the economy. The creators and suppliers of these useful rights are the bureaucrats and consumers are the business class. This demand-supply model of corruption is usually applied to analyse the tremendous economic success in Japan, South Korea and Indonesia.

Corruption is a time-old social, economic and political disease. However. widespread political and bureaucratic corruption in the post-Second World War has been due to the added responsibility which the state performs while providing economic leadership by introducing various policies for promoting economic development of the country concerned. While formulating, introducing and implementing these policies the state depends on the political and bureaucratic machinery which has the capacity to transfer economic to private individuals who may obtain an economic rent from such transfers. The bureaucrats may therefore claim a share (in the form of bribe, donations to political parties etc.) of this rent from the private sector. ${ }^{7}$ Three other factors might also be partly responsible for increase in corruption in developing countries. These are: (i) the liberalisation policies of

\footnotetext{
${ }^{7}$ The rent-seeking theory of corruption is mainly based on this reasoning
} 
the World Bank; (ii) the democratisation policies of bilateral donors; and (iii) economic globalisation.

It may seem paradoxical to argue that economic liberalisation may contribute to increased corruption in the third world. But the most recent literature on corruption asserts this proposition with empirical evidence ${ }^{8}$. For example, Harriss-White and White (1996:2) argue that evidence derived from country case studies suggest that instead of "reducing the incidence of corruption, economic liberalisation in certain contexts acts rather to displace it, redefining the character of corrupt relationships away from those initiated and controlled by state actors to those initiated and controlled by actors in civil society." The authors call this 'privatisation' of corruption. Economic liberalisation in Korea, post-Mao China and Russia have been followed by widespread corruption (Ibid., 1-2). ${ }^{9}$ Similarly, democratisation itself is not enough to get rid of corrupt politicians. Citing recent revelations from Belgium, France, Italy Japan, Spain and the United Kingdom, Hariss-White and White (1996:2) rightly argue that "pervasive political corruption can be an entrenched element of highly industrialised, democratic societies..." However, in relatively latecomers to the democratic world, corruption may sometimes be widespread and may fail to generate economic growth. For example, the process of democratisation in China, Latin America, the Philippines and Thailand since the beginning of the 1980s has "actually increased sources and scales of corruption without strengthening countervailing political or institutional capacity (Ibid.,3). ${ }^{10}$ Similarly, the globalisation of financial markets creates enormous opportunities for corruption in developing countries (Hampton:1996).

Many observers believe that corruption springs out of poor governance. The practice of systematic corruption in Sub-Saharan Africa has been linked to poor governance by many (Stevens and Gnanaselvan 1995:97). Corruption is a threat for good governance. Accountability, transparency, free flow of information are all distasteful medicine to corrupt people. Therefore any attempt to free the third world countries from corruption is bound to be faced with strong opposition.

\section{CONCLUSION}

Despite its comparatively recent origin (since 1945), the literature on economic development has been growing rapidly and with great complexity. ${ }^{11}$ It is now generally recognised that a growth of per capita real income in itself cannot be regarded as economic development. The process of development must lead to a general improvement in the standards of living of the masses, and an eradication of appalling poverty. It must also lead to better health care, more gender equality and higher and improved levels of education for the population at large. Then, there is the question of sustainability and inter-generational equity. Should economic growth cause a long term damage to environment and ecological balance it would be difficult to label it as economic development.

\footnotetext{
${ }^{8}$ For details, see Harrison-White and White (1996).

${ }^{9}$ For details of corruption in South Korea and China, see White (1996).

${ }^{10}$ See, White (1996), Jones (1996) and Sidel (1996).

${ }^{11}$ Readers should be warned that this paper is not a review of the literature on economic development. Interested readers may consult Hahn and Mathews (1964), Stern (1989), Dorfman (1991) and Rostow (1990) for this purpose.
} 
Along with the broader connotation of the development process, there has been a change of thinking on the factors which could propel change in a relatively stagnant and poor country. The Classical Economists had put emphasis on savings and investment and free market forces as crucial to growth and development. The current thinking on the growth-initiating process has moved away from purely economic factors to non-economic factors such as institutions, and cultural and historical roots. Despite the support of economic liberalisation and structural adjustment programmes from the World Bank in recent years, it is now agreed that "Markets in developing countries can be liberalized in the sense of freeing prices and yet not work well for poor people" Klitgaard (1995). Market failures in developing countries can be attributed to traditional institutions which are sometimes growth-inhibiting. The World Bank is now increasingly moving towards the position that an efficient and corruption-free administrative machinery is a precondition for economic development. It is possible (but by no means certain) that democratization of political institutions and liberalization of the economic system would facilitate the growth of a relatively corruption-free political and administrative apparatus by subjecting it to public scrutiny. 


\section{REFERENCES}

AGARWAL, VINOD B. AND WINKLER, DONALD K.(1985), Foreign Demand for United States Higher Education: A Study of Developing Countries in the Eastern Hemisphere, Economic Development and Cultural Change.

BHAGWATI, J. AND BRECHER, R.A. (1980). National Welfare in an Open Economy in the Presence of Foreign Owned Factors of Production, Journal of International Economics. (1981). Foreign Ownership and the Theory of Trade and Welfare, Journal of Political Economy.

BHAGWATI, J. AND TIRONI, E. (1980), Tariff Change, Foreign Capital and Immiserization: A Theoretical Analysis, Journal of Development Economics.

BOENINGER, EDGARDO (1992). Governance and Development: Issues and Constraints, in World Bank, Proceedings of the World Bank Annual Conference on Development Economics 1991, Wasshington, DC..

BRECHER, R.A. AND DIAZ-ALEJANDRO, C.F. (1977). Tariffs, Foreign Capital and Immiserizing Growth, Journal of International Economics, 7.

BRECHER, R.A. AND FINDLEY, R. (1983). Tariffs, Foreign Capital and National Advantage with Sector-Specific Factors, Journal of International Economics, 14.

DASGUPTA, P. AND MALER, K.-G. (1991). The Environment and Emerging Development Issues, Proceedings of the World Bank Annual Conference on Development Economics, Washington: World Bank.

DELONG, J. B. (1988). Productivity Growth, Convergence and Welfare: Comment, American Economic Review, 78 (December).

DOMAR, Evsey (1944). The 'Burden of the Debt' and the National Income, Amer. Econ. Rec., 34(5), (December).

DORFMAN, ROBERT (1991). Review Article: Economic Development from the Beginning to Rostow, Journal of Economic Literature, 29, (June).

HAHN, F.H. AND MATTHEWS (1965-66). The Theory of Economic Growth: A Survey, In American Economic Association, Surveys of Economic Theory: Growth and Development, 2, London: Macmillan, New York: St. Martin's Press .

HARRIS-WHITE, BARBARA AND WHITE, GORDON (eds.) (1996), Liberalization and the New Corruption, IDS Bulletin, 27(2), (April).

HAMPTON, MARK P (1996). Where Currents Meet: The Offshore Interface Between Corruption, Offshore Finance Centers and Economic Developemnt, In HARRIS-WHITE, BARBARA AND WHITE, GORDON (eds.) (1996), Liberalization and the New Corruption, IDS Bulletin, 27(2), (April).

HARROD, Roy F (1939). An Essay in Dynamic Theory, Econ. J., 49, (March). (1948) Towards a dynamic economics, London: Macmillan.

HARTWICK, J. (1990). Natural Resources, National Accounting and Economic Depreciation, Journal of Public Economics, 43.

(1992). Deforestation and National Accounting, Environmental and Resource Economics, 2(5).

HELLEINER, G. K. (1989). Transnational Corporations and Direct Foreign Investment, (1411-1480) In: CHENERY, HOLLIS AND T. N. SRINIVASAN (ed.) Handbook of Development Economics, (2), North-Holland: Elsevier Science Publishers B.V.

HOGENDORN, JAN S. (1992). Economic Development, Second Edition, New York: HarperCollins Publishers.

IUCN (1980). World Conservation Strategy: Living Resource Conservation for Sustainable Development. IUCN, Gland:Switzerland.

IUCN/UNEP/WWF (1991). Caring for the Earth: A Strategy for Sustainable Living, IUCN, Gland: Switzerland.

JONES, CHARLES (1996). The Argentine Debate, In HARRISS-WHITE, BARBARA AND GORDON WHITE, Liberalization and the New Corruption, IDS Bulletin, 27:2, April.

KHAN, MUSHTAQ H. (1996), A Typology of Corrupt Transactions in Developing Countries, In HARRISWHITE, BARBARA AND WHITE, GORDON (eds.) (1996), Liberalization and the New Corruption, IDS Bulletin, 27(2), (April). 
KLITGAARD, ROBERT (1995). Institutional Adjustment and Adjusting to Institutions, World Bank Discussion Paper No. 303, World Bank (September).

KRUGMAN, P. R. AND VENABLES, A. (1995). Globalization and the Inequality of Nations, NBER Working Paper No. 5098, Cambridge: National Bureau of Economic Research, (April).

LANDELL-MILLS, PIERRE AND SERAGELDIN (1992). Governance and the External Factor, in World Bank, Proceedings of the World Bank Annual Conference on Development Economics 1991, Wasshington, DC.

LANCASTER, CAROL (1993). Governance and Development: The Views from Washington, IDS Bulletin, 24(1).

LEFF, N. (1979). Economic Development Through Bureaucratic Corruption, In EKPO, M. U. (ed.). (1979). Bureaucratic Corruption in Sub-Saharan Africa: Towards a Search for Causes and Consequences, Washington: University Press of America.

LEFTWICH, ADRIAN (1994). Governance, the State and the Politics of Development, Development and Change, 25(2), (April).

MÄLER, KARL-GORÄN (1991). National Accounting and Environmental Resources, Environmental and Resource Economics, 1(1).

MUNRO, DAVID A.(1995). Sustainability: Rhetoric or Reality? IN: TRZYNA, THADDEUS C. (ed). A Sustainable World, Sacrament: Published for IUCN - The World Conservation Union by the International Center for the Environment and Public Policy, California Institute of Public Affairs.

MOORE, MICK (1993). Introduction, IDS Bulletin, 24(1), (January). (ed.) (1993a). Good Government? IDS Bulletin, 21(1), (January).

(ed.) (1993b). Declining to Learn from the East? The World Bank on 'Governance and Development', In MOORE, MICK (ed.).Good Government? IDS Bulletin, 24(1), (January).

O'BRIEN, STEVE (1994). Some Reflections on Country Experiences with Structural Adjustment. IDS Bulletin, 25(3).

PREBISCH, R. (1962). The Economic Development of Latin America and Its Principal Problems, Economic Bulletin for Latin America, 7,(February).

PEARCE, DAVID W. ET AL. (1989). A Blueprint for a Green Economy, London: Earthscan.

REPETTO, ET. AL. (1989). Wasting Assets, Natural Resources in the National Accounts, Washington: World Resources Institute.

REPETTO, ET. AL. (1992). Accounts Overdue: Natural Resource Depreciation in Costa Rica, Washington:World Resources Institute.

ROBINSON, MARK (1995). Towards Democratic Governance. IDS Bulletin, 26(2), April.

ROSTOW, W. W. (1990). Theorists of Economic Growth from David Hume to the Present: With a Perspective on the Next Century, New York: Oxford University Press.

RUFFIN, ROY J. (1993). The Role of Foreign Investment in the Economic Growth of the Asian and Pacific Region, Asian Development Review, 11(1).

SAMANTA P C (1996). Review of Structural Adjustment Programmes in Developing Countries: The Case of Kenya, in SIDDIQUE, M A B, ET AL. (1996). Economic Development and Change: South Asia and the Third World, New Delhi: New Age International Limited, Publishers.

SIDEL, JOHN T (1996). Siam and its Twin? Democratization and Bossism in Contemporary Thailand and the Philippines, In HARRISS-WHITE, BARBARA AND GORDON WHITE (1996) Liberalization and the New Corruption, IDS Billetin, 27:2, April.

SIDDIQUE, M A B (1996). External Debt Problem of Sub-Saharan Africa: 1971-90. The South African Journal of Economics, 64 (2), June.

SIDDIQUE, M A B, ET AL. (1996a). Economic Development and Change: South Asia and the Third World, New Delhi: New Age International Limited, Publishers.

SINGER, H. B. (1950). The Distribution of Gains Between Borrowing and Investing countries, American Economic Review, 40.

STERN, NICHOLAS (1989). The Economics of Development: A Survey, The Economic Journal, 99, (September).

STEVENS, MIKE AND GNANASELVAM (1995). The World Bank and Governance. IDS Bulletin, 26(2), (April).

WHITE, GORDON (1996). Corruption and Market Reform in Chine, In HARRISS-WHITE, BARBARA AND GORDON WHITE, Liberalization and the New Corruption, IDS Billetin, 27:2, April. 
WILLIAMSON, JEFFREY G (1996). Globalization, Convergence, and History, The Journal of Economic History, 56(2), (June).

WORLD BANK (1989). Sub-Saharan Africa: From Crisis to Sustainable Growth, Washington D C. (1992a). Governance and Development, Washington D C. (1992b). Proceedings of the World Bank Annual Conference on Development Economics 1991, Wasshington, DC.

(1994). Governance: The World Bank's Experience: Executive Summary, [Online] Available: http://www.worldbank.org/html/hcovp/reports/governan.html. (1995). Distribution and growth: Complements, not compromises, World Bank Policy Research Bulletin[Online],6(3),Available:

http://www.worldbank.org/html/dec/Publications/Bulletins/prb6,3.html[1995, May-July].

WORLD COMMISSION ON ENVIRONMENT AND DEVELOPMENT (1987). Our Common Future, Oxford: Oxford University Press. 